\title{
PENERAPAN MODEL PEMBELAJARAN KOOPERATIF TIPE JIGSAW PADA PEMBELAJARAN FISIKA KELAS X SMKN 2 PINRAN
}

\author{
Sukriadi, Sixtus Iwan Umboh, Jimmy Lolowang \\ Fakultas Matematika dan Ilmu Pengetahuan Alam, Universitas Negeri Manado \\ email: Sukriadicuke7@gmail.com
}

\begin{abstract}
ABSTRAK
Penelitian ini adalah penelitian eksperimen semu yang bertujuan untuk mengetahui adakah pengaruh positif pembelajaran kooperatif tipe Jigsaw terhadap hasil belajar siswa kelas X SMK Negeri 2 PINRANG (Pada materi gerak lurus). Desain penelitian adalah "Pretest-Posttest Control Group Design". Variabel dalam penelitian ini adalah model pembelajaran dan hasil belajar. Variabel bebas dalam penelitian ini adalah pembelajaran kooperatif Jigsaw dan pembelajaran langsung, sedangkan variabel terikatnya adalah hasil belajar siswa. Populasi dalam penelitian ini adalah seluruh siswa kelas X SMK NEGERI 2 PINRANG. Adapun sampel dalam penelitian ini terdiri dari dua kelas yaitu kelas X APH1 sebagai kelas eksperimen dan kelas X APH2 sebagai kelas control dengan teknik pengambilan sampel melalui random sampling. Jumlah siswa masingmasing kelas adalah 12 siswa pada kelas X APH1 dan 12 siswa pada kelas X APH 2. Pengambilan data hasil belajar dilakukan dengan pemberian pretest dan posttest yang selanjutnya dianalisis menggunakan SPSS. Hasil analisis menunjukkan nilai rata-rata kelas eksperimen 75 dan kelas kontrol 42.5 dengan standar deviasi berturut-turut adalah 9.29 dan 15. Hasil analisis SPSS dengan menggunakan uji-t diperoleh bahwa nilai $t_{\text {hitung }}=>t_{\text {tabel }}=6.38>1.717144$. Oleh karena, $t_{\text {hitung }}>$ $\mathrm{t}_{\text {tabel }}$,berarti $\mathrm{H}_{0}$ ditolak dan $\mathrm{H}_{1}$ diterima.
\end{abstract}

Kata kunci : Jigsaw, Hasil belajar, gerak lurus

\begin{abstract}
This research is quasi-experimental research aimed at determining whether Jigsaw's collaborative learning has a positive effect on the learning outcomes of Grade X SMK Negeri 2 PINRANG (on straight motion material) students. The research design was "Pretest-Posttest Control Group Design". The variables in this study are the learning model and the learning outcomes. The independent variable in this study is cooperative jigsaw learning and direct learning, while the dependent variable is student learning outcomes. The population in this study were all grade $X$ SMK NEGERI 2 PINRANG students. The sample in this study consisted of two classes, namely Class X APH1 as the experimental class and Class X APH2 as the control class with the sampling technique by random sampling. There are 12 students in class $X$ APH1 and 12 students in class $X$ APH 2 in each class. The results of the analysis show that the mean of the experimental class is 75 and the control class is 42.5 with a standard deviation of 9.29 and 15, respectively. The results of the SPSS analysis using the $t$-test show that the value of $t=>$ is $t$ table $=6.38>1.717144$. Therefore tcount> ttable means that $\mathrm{HO}$ is rejected and $\mathrm{HI}$ is accepted.
\end{abstract}

Keywords : : Jigsaw, learning outcomes, straight motion 


\section{PENDAHULUAN}

Pendidikan merupakan salah satu pilar dalam pembangunan bangsa. Pendidikan memiliki peran yang sangat penting dalam membentuk sumber daya manusia agar menjadi individu yang berkualitas. Undang-undang No. 20 Tahun 2003 tentang Sistem Pendidikan Nasional menyatakan bahwa fungsi dan tujuan pendidikan nasional adalah mengembangkan kemampuan dan membentuk watak serta peradaban bangsa yang bermartabat dalam rangka mencerdaskan kehidupan bangsa, bertujuan untuk berkembangnya potensi peserta didik agar menjadi manusia yang beriman dan bertakwa kepada Tuhan Yang Maha Esa, berakhlak mulia, sehat, berilmu, cakap, kreatif, mandiri, dan menjadi warga negara yang demokratis serta bertanggung jawab. Saat ini pemerintah telah menetapkan kurikulum 2013 sebagai kurikulum yang paling terbaru berdasarkan refleksi dari kurikulum sebelumnya. Peran kurikulum ini sangat berpengaruh terhadap proses dari pendidikan itu sendiri.

Siswa diharapkan memiliki motivasi yang tinggi melalui kegiatan mencari dan menemukan solusi terhadap masalah yang ada sesuai dengan metode ilmiah. Belajar penemuan merupakan cara belajar yang dapat menghasilkan motivasi yang baik.

Berdasarkan fakta-fakta yang diperoleh, maka dapat ditarik kesimpulan bahwa rendahnya hasil belajar siswa diakibatkan oleh rendahnya motivasi belajar yang dimiliki siswa.

Beranjak dari masalah-masalah yang telah diuraikan saat ini siswa mengalamikesulitan dalam belajar akibat penggunaan strategi belajar yang kurang tepat (Ulstad et al,2016). Hal tersebut juga senada dengan hasil observasi yang dilakukan pada saat siswa masih kelas $\mathrm{X}$ oleh peneliti terhadap proses pembelajaran fisika pada mata pelajaran fisika tergolong rendah. Rendahnya hasil belajar siswa kelas X SMKN 2 Pinrang semester ganjil tahun ajaran 2019/2020.

Rendahnya hasil belajar siswa kelas $\mathrm{X}$ SMKN 2 Pinrang ditemukan bahwa nilai ulangan akhir semester genap siswa kelas IPA pada mata pelajaran fisika tergolong rendah. Rendahnya hasil belajar siswa kelas X SMKN 2 Pinrang tercermin dari nilai ulangan akhir semester mata pelajaran fisika yang disajikan pada tabel 1
Tabel 1. Data nilai siswa kelas X SMKN 2 Pinrang (2019/2020)

\begin{tabular}{|l|c|}
\hline \multicolumn{1}{|c|}{ Aspek } & UAS \\
\hline Nilai tinggi & 51 \\
\hline Nilai rendah & 10 \\
\hline Rata - rata & 46,56 \\
\hline Frekuensi KKM & 0 \\
\hline Frekuensi KKM & 33 \\
\hline Aspek & UAS \\
\hline Ketuntasan kilasikal \% & $0 \%$ \\
\hline
\end{tabular}

Tabel di atas menunjukkan hasil observasi yang dilakukan oleh peneliti terhadap proses pembelajaran fisika saat kelas X SMKN 2 Pinrang(2019/2020) ditemukan bahwa nilai ulangan akhir semester genap pada mata pelajaran fisika masih tergolong rendah, sehingga hasil observasi saat kelas $\mathrm{X}$ masih terbilang rendah dengan hasil belajar pada semester ganjil tahun ajaran 2019/2020.

Berdasarkan identifikasi permasalahan tersebut, maka perlu adanya perbaikan proses pembelajaran. Solusi untuk mengatasi permasalahan tersebut adalah strategi pembelajaran yang dapat merangsang atau memotivasi siswa seperti membentuk kelompok ahli dengan kelompok asalnya untuk memperoleh hasil belajar yang baik. Berdasarkan uraian tersebut, maka salah satu alternatif yang ditawarkan untuk bisa meningkatkan hasil belajar siswa adalah menerapkan model pembelajaran kooperatif tipe Jigsaw).

Pembelajaran kooperatif Jigsaw merupakan pembelajaran dimana siswa bertanggung jawab untuk belajar materi dan mengajarkannya kepada siswa lainnya. Pembelajaran kooperatif Jigsaw mampu meningkatkan berbagai pengalaman belajar dan mengajar serta dapat meningkatkan keterampilan sosial siswa (Perkins \& Tagle dalam Karacop, 2017).

Berdasarkan uraian tersebut maka dipandang perlu dilaksanakannya penelitian lebih lanjut untuk memperoleh data yang menunjukkan pengaruh model pembelajaran yang diterapkan oleh guru terhadap motivasi dan hasil belajar siswa (Syahputra, 2014). Oleh karena itu, diajukan sebuah penelitian yang berjudul: "Penerapan Model Pembelajaran Kooperatif Tipe Jigsaw Pada Pembelajaran Fisika Kelas X Smkn 2 Pinrang)”. 


\section{METODE PENELITIAN}

Dilihat dari sudut pandang siswa diambil kesimpulan bahwa sifat dan permasalahan penelitian ini termasuk penelitian eksperimen.Penelitian eksperimen ini termasuk desain kelompok pretest-posttest kontrol dan kelompok eksperimen pretest-posttest (one group class kontrol-eksperimen design). Desain eksperimen bentuk ini hampir sama dengan bentuk desain keolompok tunggal tanpa pra-test (The one-shot case study).Perbedaanya adalah sebelum diberikan perlakuan, terlebih dahulu subjek diberikan tes yang disebut dengan pra-test. Bentuk desain eksperimen dapat dilihat di bawah ini :

Tabel 2 pretest-posttest (one group class kontroleksperimen design)

\begin{tabular}{crc}
\hline & Kontrol & (Eksperimen) \\
\hline$T_{1}$ & $X$ & $T_{2}$ \\
\hline
\end{tabular}

\section{Keterangan :}

$\boldsymbol{T}_{\mathbf{1}}$ : Test awal pada kelompok kontrol

$\boldsymbol{X}$ : Melakukan model pembelajaran Jigsaw yang diberikan perlakuanselama jangka waktu tertentu

$\boldsymbol{T}_{2}$ : Test akhir pada kelompok eksperimen

Prosedur penelitian dilakukan dengan tahap-tahap sebagai berikut :

a) Menyiapkan instrumen penelitian berupa test awal untuk menguji pemahaman siswa dan test akhir untuk melihat perkembangan siswa setelah mendapat perlakuan, serta instrument penilaian aktivitas belajar siswa.

b) Melaksanakan test kontrol pretest-posttest

c) Menganalisis hasil kontrol pretestposttest

d) Melaksanakan eksperimen pembelajaran dengan menggunakan model pembelajaran Jigsaw, serta mengobservasi.

e) Melaksanakan test eksperimen pretestposttest

f) Menganalisis hasil eksperimen pretestposttest

Hasil pengukuran hasil belajar siswa dianalisis menggunakan SPSS, hasil belajar siswa dianalisis menggunakan independent sample t-test untuk menarik kesimpulan dari penelitian yang telah dilakukan.

Analisis yang digunakan dalam penelitian untuk data-data yang diperoleh selama penelitian ini di analisis dengan rumusrumus statistik :

(a) Hasil belajar siswa

Untuk menguji pengaruh model pembelajaran Jigsaw terhadap hasil belajar siswa, maka di lakukan dianalisis menggunakan nilai pre-test dan posttest sebagai hasil dari eksperimen dengan menggunakan program SPSS.

1. Uji Homogenitas

a. Uji homogenitas bertujuan untuk mengetahui apakah suatu varians (keberagaman) data dari dua lebih kelompok bersifat homogen (sama) atau heterogen (tidak sama).

b. Data yang homogen merupakan salah satu syarat (bukan syarat mutlak) dalam uji independent sample $t$ test

c. Dalam penelitian ini, uji homogenitas digunakan untuk mengetahui apakah varians data post-test kelas eksperimen (Jigsaw) dan data posttest kelas kontrol (konvensional) bersifat homogen atau tidak.

Pada penelitian ini, uji homogenitas menggunakan program pengolah data SPSS versi 22 . Kriteria pengujiaanya adalah apabila nilai Sig.(Signifikansi) atau nilai probabilitas $<0.05$ maka variansi setiap sampel dikatakan tidak homogen, sedangkan jika nilai Sig.(Signifikansi) atau nilai probabilitas $>0.05$ maka variansi setiap sampel dikatakan homogeny (Santoso, 2003).

2. Uji Normalitas Data

Uji normalitas bertujuan untuk mengetahui apakah penyebaran kedua populasi berdistribusi secara normal atau tidak, untuk mengetahuinya maka peneliti menggunakan program pengolah data SPSS 22 (Statistical ProductandService Solution) dengan uji normalitas one sample Shapiro-Wilk. Kriteria pengujiannya adalah jika nilai Sig. (Signifikansi) atau nilai probabilitas $<0.05$ maka distribusi adalah tidak normal, sedangkan jika nilai Sig. (Signifikansi) atau nilai probabilitas $>0.05$ makadistribusiadalah normal (Santoso, 2003).

3. Uji Hipotesis

Uji $t$ untuk varian yang sama menggunakan rumus Polled Varianssebagai berikut: 


$$
t_{\text {hitung }}=\frac{\overline{x_{1}-\overline{x_{2}}}}{\sqrt[s]{\frac{\left(n_{1}-1\right) s_{1}^{2}+\left(n_{2}-1\right) s_{2}^{2}}{n_{1}+n_{1}-2}\left(\frac{1}{n_{1}}+\frac{1}{n_{2}}\right)}}
$$

Sedangkan Uji t untuk varian yang berbeda menggunakan rumus Separated Varians sebagai berikut:

$$
t_{\text {hitung }}=\frac{\overline{x_{1}^{-}-x_{2}^{-}}}{\sqrt{\frac{s_{1}^{2}}{n_{1}}+\frac{s_{2}^{2}}{n_{2}}}}
$$

Rumus yang dignakan dalam penelitian ini adalah rumus Uji t untuk varian yang berbeda. Keterangan :

$\overline{x_{1}}=$ rata - rata nilai kelompok eksperimen

$\overline{x_{2}}=$ rata - rata nilai kelompok kontrol

$n_{1}=$ jumlah sampel untuk kelompok eksperimen

$n_{2}=$ jumlah sampel untuk kelompok kontrol

$s_{1}^{2}=$ varian kelompok eksperimen

$s_{2}^{2}=$ varian kelompok kontrol

\section{HASIL DAN PEMBAHASAN}

Belajar dilakukan untuk mengusahakan adanya perubahan perilaku pada individu yang belajar. Aspek perubahan itu mengacu kepada taksonomi tujuan pengajaran yang dikembangkan oleh Bloom, Simpson, dan Harrow mencakup aspek kognitif, afektif dan psikomotorik (Winkel dalam Purwanto, 2014).

Berdasarkan penjelasan diatas dapat kita simpulkan bahwa hasil belajar adalah kemampuan-kemampuan yang dimiliki siswa setelah menerima pengalaman belajarnya. Kemampuan-kemampuan tersebut mencakup aspek kognitif, afektif, dan psikomotorik. Pada proses kognitif, prosesnya mengakibatkan perubahan dalam aspek kemampuan berpikir (cognitive), pada belajar afektif mengakibatkan perubahan dalam aspek kemampuan merasakan (afective), sedangkan belajar psikomotorik memberikan hasil belajar berupa ketrampilan (psychomotoric). Hasil belajar dapat dilihat melalui kegiatan evaluasi yang bertujuan untuk mendapatkan data pembuktian yang akan menunjukkan tingkat kemampuan siswa dalam mencapai tujuan pembelajaran.

Berdasarkan penelitian yang relevan, diperoleh kesimpulan bahwa model pembelajaran Jigsaw berpengaruh terhadap hasil belajar, hal ini membuat peneliti tertarik untuk melakukan penelitian yang serupa. Peneliti berpendapat bahwa masalah dalam pembelajaran tematik akan menarik apabila dipecahkan dengan menggunakan model Jigsaw. model pembelajaran Jigsaw merupakan salah satu model pembelajaran yang dapat meningkatkan keberhasilan belajar peserta didik. Kelebihan pembelajaran model Jigsaw ini diantaranya mengaktifkan seluruh otaknya, fokus kepada pokok bahasan, membantu menunjukan hubungan antara bagian-bagian informasi yang saling terpisah. Sehingga akan berpengaruh terhadap hasil belajar.

Dalam penelitian ini data yang diambil adalah hasil belajar siswa pada mata pelajaran Gerak lurus.

Data hasil tes awal pada kelas kontrol dan eksperimen dapat dilihat pada tabel 3

Tabel 3 Ringkasan Data Hasil Pre-test Kelas

\begin{tabular}{|c|c|c|c|}
\hline NO & DATA & $\begin{array}{c}\text { KONTROL } \\
\text { PRE-TEST }\end{array}$ & $\begin{array}{c}\text { EKSPERIMEN } \\
\text { PRE-TEST }\end{array}$ \\
\hline 1 & JUMLAH & 330 & 295 \\
\hline 2 & $\begin{array}{l}\text { NILAI } \\
\text { MINIMAL }\end{array}$ & 15 & 10 \\
\hline 3 & $\begin{array}{l}\text { NILAI } \\
\text { MAKSIMAL }\end{array}$ & 55 & 55 \\
\hline 4 & $\begin{array}{l}\text { RATA - } \\
\text { RATA }\end{array}$ & 27.5 & 24.5 \\
\hline 5 & VARIAN & 120.45 & 138.44 \\
\hline 6 & $\begin{array}{l}\text { STANDAR } \\
\text { DEVISIASI }\end{array}$ & 10.97 & 11.76 \\
\hline 7 & MEDIAN & 25 & 20 \\
\hline 8 & MODUS & 25 & 15 \\
\hline
\end{tabular}
Kontrol dan Eksperimen

Tabel 4 Ringkasan Data Hasil Pre-test Kelas

\begin{tabular}{|c|c|c|c|}
\hline \multirow[b]{2}{*}{ NO } & \multirow[b]{2}{*}{ DATA } & KONTROL & EKSPERIMEN \\
\hline & & $\begin{array}{c}\text { POST- } \\
\text { TEST }\end{array}$ & POST-TEST \\
\hline 1 & JUMLAH & 510 & 900 \\
\hline 2 & $\begin{array}{l}\text { NILAI } \\
\text { MINIMAL }\end{array}$ & 25 & 60 \\
\hline 3 & $\begin{array}{l}\text { NILAI } \\
\text { MAKSIMAL }\end{array}$ & 65 & 85 \\
\hline 4 & RATA - RATA & 42,5 & 75 \\
\hline 5 & VARIAN & 225 & 86.36 \\
\hline 6 & $\begin{array}{l}\text { STANDAR } \\
\text { DEVISIASI }\end{array}$ & 15 & 9.29 \\
\hline 7 & MEDIAN & 40 & 77,5 \\
\hline 8 & MODUS & 55 & 80 \\
\hline
\end{tabular}
Kontrol dan Eksperimen

1. Uji Homogenitas

a). Uji melalui pre-test pada kelas kontrol dan eksperimen

Syarat Kriteria Uji :

1. $\mathrm{H}_{0}$ diterima jika harga signifikansi (Sig.)< 0,05 ,

2. $\mathrm{H}_{1}$ diterima jika harga ( $\left.\mathrm{Sig}.\right)>0,05$ 
Tabel 5 Uji Homogenitas Pre-Test kelas Kontrol dan Eksperimen

Test of Homogeneity of Variances

\begin{tabular}{crrr} 
PRETEST & & & \\
\hline $\begin{array}{c}\text { Levene } \\
\text { Statistic }\end{array}$ & $\mathrm{df1}$ & $\mathrm{df2}$ & \multicolumn{1}{c}{ Sig. } \\
\hline .334 & 1 & 22 & .569 \\
\hline
\end{tabular}

Berdasarkan Test of Homogeneity of Variances diperoleh nilai Sig 0.569> $\alpha=(0,05)$ maka $\mathrm{H}_{1}$ diterima atau dengan kata lain tidak terdapat perbedaan varians populasi antara nilai pre-test kelas eksperimen dengan pre-test kelas Kontrol. Artinya,varians populasi data nilai kelas kontrol dan kelas eksperimen homogen.

b). Uji Melalui Post-Test Kelas Kontrol dan Eksperimen

Tabel 6 Uji Homogenitas Post-Test kelas Kontrol dan Eksperimen

Test of Homogeneity of Variances

\begin{tabular}{cccc}
$\begin{array}{c}\text { POSTEST } \\
\begin{array}{c}\text { Levene } \\
\text { Statistic }\end{array}\end{array}$ & df1 & df2 & Sig. \\
\hline 7.284 & 1 & 22 & .013 \\
\hline
\end{tabular}

Berdasarkan Test of Homogeneity of

Variances diperoleh nilai Sig $0.013<\alpha(0,05)$ maka $\mathrm{H}_{0}$ diterima atau dengan kata lain terdapat perbedaan varians populasi antara nilai posttest kelas eksperimen dengan post-test kelas Kontrol. Artinya, varians populasi data nilai kelas kontrol dan kelas eksperimen tidak homogen. Karena sampel penelitian ini besifat Independent atau berdiri sendiri, maka uji homogeny Post-test dapat diabaikan sehingga uji hipotesis dapat dilanjutkan.

2. Uji Normalitas Data

a) Uji melalui pre-test kelas kontrol dan eksperimen

Syarat Kriteria Uji :

1. $\mathrm{H}_{0}$ diterima jika harga signifikansi (Sig.)< 0,05 ,

2. $\mathrm{H}_{1}$ diterima jika harga (Sig.) $>0,05$

Tabel 7. Uji Normalitas Data Pre-Test Kontrol dan Pre-Test Eksperimen

\begin{tabular}{|c|c|c|c|c|c|c|c|}
\hline & & \multicolumn{3}{|c|}{$\begin{array}{c}\text { Kolmogorov- } \\
\text { Smirnov }^{\mathrm{a}}\end{array}$} & \multicolumn{3}{|c|}{ Shapiro-Wilk } \\
\hline & & Statist & & & Statist & & \\
\hline & KELAS & ic & Df & Sig. & ic & Df & Sig. \\
\hline \multirow[t]{2}{*}{$\begin{array}{l}\text { PRET } \\
\text { EST }\end{array}$} & $\begin{array}{l}\text { KONTR } \\
\text { OL }\end{array}$ & .173 & 12 & $.200^{*}$ & .879 & 12 & .084 \\
\hline & $\begin{array}{l}\text { EKSPE } \\
\text { RIMEN }\end{array}$ & .235 & 12 & .066 & .883 & 12 & .096 \\
\hline
\end{tabular}

Berdasarkan pengujian data pada output table SPSS menyatakan bahwa nilai signifikasi atau sig. pada uji normalitas ShapiroWilkuntuk kelas kontrol sebesar 0.084 dan kelas eksperimen sebesar 0.096 Maka kedua nilai Sig. tersebut $>0.05$, dengan demikian maka disimpulkan data Pre-Test Kontrol dan Eksperimen berdistribusi Normal.

b) Uji Normalitas Post-Test Kontrol dan Eksperimen

Syarat Kriteria Pengujian :

1. $\mathrm{H}_{0}$ diterima jika harga signifikansi (Sig.) $<0,05$,

2. $\mathrm{H}_{1}$ diterima jika harga (Sig.) $>0,05$

Tabel 8. Uji Normalitas Data Post-Test Kontrol dan Eksperimen

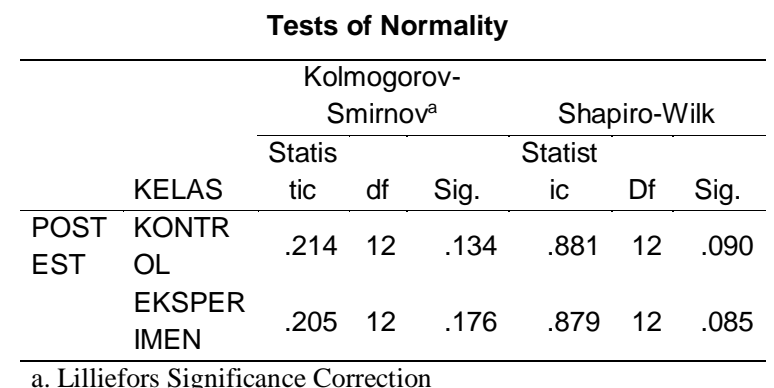

Berdasarkan pengujian data pada output table SPSS menyatakan bahwa nilai signifikasi atau sig. pada uji normalitas ShapiroWilkuntuk kelas kontrol sebesar 0.09dan kelas eksperimen sebesar 0.085 maka kedua nilai Sig. tersebut> 0,05, dengan demikian maka disimpulkan data Pos-TestKontrol dan Eksperimen berdistribusi Normal.

3. Uji Hipotesis

Oleh karena uji normalitas dan homogenitas sudah terpenuhi, maka hipotesis dapat dilakukan.

Keputusan :

1. Langkah - langkah $\quad \mathrm{H}_{0}: \mu_{1} \leq \mu_{12}$

2. Kriteria uji :

$\mathrm{H}_{1}: \mu_{1}>\mu_{2}$

$\mathrm{H}_{0}$ diterima jika harga $\mathrm{t}_{\text {hitung }} \leq \mathrm{t}_{\text {tabel }}$ dan ,

$\mathrm{H}_{1}$ diterima jika harga $\mathrm{t}_{\text {hitung }}>\mathrm{t}_{\text {tabel }}$

Dimana :

$\mu_{1}=$ rata - rata hasil belajar siswa kelas eksperimen yang menggunakan model pembelajaran Jigsawterhadap hasil belajar siswa.

$\mu_{2}=$ rata - rata hasil belajar siswa kelas kontrol yang menggunakan model ceramah

Probabilitas $\alpha=0,05$

Berdasarkan hasil penghitungan pada 
lampiran uji hipotesis diketahui bahwa harga $\mathrm{t}_{\text {hitung }}>\mathrm{t}_{\text {tabel }}$ yaitu $6.38>1.717144$ maka dapat disimpulkan bahwa H1 di terima yaitu terdapat pengaruh model pembelajaran Jigsaw terhadap hasil belajar siswa.Dengan demikian dapat disimpulkan bahwa $\mathrm{H}_{1}$ diterima dan $\mathrm{H}_{0}$ ditolak.

Setelah pembelajaran teknologi dasar otomotif dan nilai diterapkan pada masingmasing kelas dengan metode pembelajaran yang berbeda, dimana pembelajaran kelas eksperimen menggunakan model pembelajaran Jigsaw sedangkan kelas kontrol menggunakan model pembelajaran konvensional kemudian dilakukan pengujian post-test kelompok kontrol dan eksperimen.

Dari Analisis pre-test dan post-test yang telah diuraikan menunjukan bahwa skor minimum hasil belajar siswa yang diberikan perlakuan dengan menggunakan model pembelajaran Jigsaw adalah 60 dan skor masksimum yang dicapai adalah 85 sedangkan skor minimum yang dicapai dari hasil belajar siswa yang diberikan perlakuan dengan model pembelajaran konvensional adalah 25 dan skor maksimum yang dicapai adalah 65 .

Selanjutnya dilakukan uji homogenitas (uji statistik Levene) dengan taraf signifikansi 5\% (0.05) dimana nilai Sig. yang diperoleh sebesar 0.013 atau dengan kata lain terdapat perbedaan varians populasi data nilai post-test kelompok eksperimen dengan post-test kelompok kedua kelompok tidak homogen. Walaupun hasil pengujian post-test kelas eksperimen dengan post-test kelas kontrol tidak homogen, pengujian hipotesis tetap dapat dilakukan karena kedua sampel independent atau tidak saling mempengaruhi.

Selanjutnya dilakukan uji normalitas Shapiro-Wilk dengan taraf signifikansi 5\% dimana hasil pengujian menunjukkan kedua kolompok normal dimana diperoleh nilai Sig. untuk post-test control sebesar 0.09 dan posttest eksperimen sebesar 0.085.berdasarkan kedua nilai Sig. tersebut disimpulkan persebaran data kedua kelompok adalah normal.

Setelah dilakukan pengujian homogenitas dan normalitas, makaselanjutnya adalah pengujian hipotesis dengan menggunakan metode T-test dimana pengujian ini mengguunakan perbandingan Thitung dan Ttabel. Kriteria pengujiannya adalah jika $t_{\text {hitung }}$ $>t_{\text {tabel }}$ maka dapat disimpulkan model pembelajaran Jigsaw memberikan pengaruh signifikan terhadap hasil belajar siswa pada mata pelajaran Gerak lurus. Karena pada penghitungan diperoleh $t_{\text {hitung }}>t_{\text {tabel }}$ maka dapat disimpulkan bahwa penggunaan model pembelajaran Jigsaw berpengaruh terhadap hasil belajar siswa pada mata pelajaran Gerak lurus di SMKN 2 PINRANG.

Berdasarkan hasil penelitian bahwa penggunaan model pembelajaran Jigsaw memberikan pengaruh terhadap hasil belajar siswa dimana diperoleh $\mathrm{t}_{\text {hitung }}=6.38>\mathrm{t}_{\text {tabel }}=$ 1.717144 .

\section{KESIMPULAN}

Berdasrkan hasil penelitian dan pembahasan dapat disimpulkan bahwa terdapat perbedaan hasil belajar Kelas kontrol dan kelas eksperimen perlakuan menggunakan Model Kooperatif Tepe Jigsaw. Hal ini dapat dilihat dari perbedaan hasil pretest posttest juga nilai dari $t_{\text {hitung }}$ dan nilai $t_{\text {tabel}}$, yang menunjukkan bahwa $t_{\text {hitung }}>t_{\text {tabel. }}$. Dengan demikian disimpulkan bahwa model pembelajaran Kooperatif Tipe Jigsaw pada Pembelajaran Fisika Materi Gerak Lurus berpengaruh terhadap hasil belajar siswa Kelas X SMKN 2 Pinrang (2020/2021).

\section{REFERENSI}

Pristiadi Utomo. 2014. Kurikulum 2013. Fisika Untuk SMK/MAK Kelas $X$. Penerbit Erlangga.

Sugiyono. 2014. Metode Penelitian Pendidikan. Bandung : Alfabeta

Depdiknas. 2003. Undang-Undang RI No. 20 tahun 2003. Tentang Sistem Pendidikan Nasional.

Abbas, H. M. (2019). Penerapan Pembelajaran Model Jigsaw Untuk Meningkatkan. Jurnal Pendidikan Fisika Dan Teknologi, 270-277.

Malau , J. (2014). Pembelajaran Kooperatif Tipe Jigsaw Dalam Pembelajaran Fisika. Jurnal Formatif 4 Issn: 2088-351x, 1-10.

Naibaho, G. D. (2011). Penerapan Model Pembelajaran Kooperatif Tipe Jigsaw Untukmingkatkan Hasil Belajar Fisika Padakonsep Zat Di Kelas Vii Smp Negeri 3 Hinai. Urnal Pendiddikan Fisika, 59-64.

Sarwanto, J. S. (2013). Penerapan Pembelajaran Fisika Model Kooperatif Tipe Jigsaw Untuk Meningkatkan Aktivitas Dan Hasilbelajar Fisika Siswa Di Smp. Jurnal Pendidikan Fisika, 34-40. 
Suparmi \&, W. F. (2016). Pembelajaran Fisika Menggunakan Model Jigsaw Dan Gi (Group Investigation) Ditinjau Dari Kreativitasdan Sikap Ilmiah Belajar Siswa. Jurnal Inkuiri , Vol 5, No. 3, 2016 (Hal 40-48.

Tumanggo, V. Y. (2018). Penerapan Model Pembelajaran Kooperatif Tipe Jigsaw Untuk Meningkatkan Motivasi Dan Hasil Belaarsiswa Pada Pembelaaran Fisika Siswa Kelas Xi Mipa Di Sma 2 Singaraja. Jppf, 31-44.

Kemendikbud. (2017). Direktur Jendral Pendidikan Dasar dan Menengah Tentang Kompetensi Inti Dan Kompetensi Dasar, Jakarta: Kementrian Pendidikan dan Kebudayaan RI 